\title{
RELATIONSHIP BETWEEN BREAST-FEEDING \& BOTTLE-FEEDING TO CRANIOFACIAL \& DENTAL DEVELOPMENT
}

Z. Radzi, N.A. Yahya. Relationship between breastfeeding \& bottle-feeding to craniofacial \& dental development. Annal Dent Univ Malaya 2005; 12: 917.

\begin{abstract}
Breast-feeding offers many benefits to the baby and the mother. For instance, breast milk provides the right balance of nutrients to help an infant grow into a strong and healthy toddler. Even though breastfeeding is a natural process, it is not always easy. In certain situations, some mothers are unable to breastfeed their babies or the babies are unable to adapt to breastfeeding. This will lead to the use of bottle-feeding. The effect of breast-feeding and bottle-feeding on physical growth has been well established but less has been concentrated on the craniofacial growth and dental development. This review reveals the effects of breast-feeding and bottle-feeding on craniofacial growth and dentoalveolar development based on the available literature.
\end{abstract}

Key words: Breast-feeding, bottle-feeding, craniofacial development, and orthodontics.

\section{INTRODUCTION}

The basic material of an infant's diet is milk. It can be either breast or formula milk (1). Breast milk is a living, cellular and complex fluid. It has more than two hundred known constituents that constantly change to meet the needs of the infant (2). Among the constituents are hormones, biological amine, growth factor and enzymes (3). Formula milk on the other hand is a type of processed milk that contains proportions of milk and other constituents. It can be preserved either by canning or drying. Many of the substances found in breast milk cannot be reproduced in formula milk such as some nutrient compounds, cells, hormones, enzymes, prostaglandin, antibodies, antibacterial and antiviral factors (4).

Thus, breast milk is widely accepted as the ideal source of nutrition for infants while breast-feeding is considered as the optimal method of infant feeding (5). In order to ensure success in breastfeeding; it is important that breast-feeding is initiated as early as possible during the neonatal period. The infant must learn to attach and suckle properly at the breast during the first few days of life (6).
Original Article

Z. Radzi1, N.A. Yahya ${ }^{2}$
'Department of Children's Dentistry \&
Orthodontics
Faculty of Dentistry, University of Malaya
50603, Kuala Lumpur.
2Department of Conservative Dentistry
Faculty of Dentistry, University of Malaya
50603, Kuala Lumpur.
Corresponding author - Dr Zamri Radzi

The other methods of feeding are cup, spoon, tube and bottle. It can be used either as an alternative or as a supplement (7). Supplemental formula feeding is strongly associated with early breast-feeding termination. It is believed that exposure to artificial nipple may contribute to breast-feeding problems and early weaning (6). However, randomized controlled trials provide conflicting evidence on this matter $(8,9 \& 10)$.

It has becoming clear that breast-feeding confers health, psychological, nutritional and immunologic advantages ( $6 \& 11)$. Breast milk is recognized as the gold standard for the nourishment of human babies, as it provides all the essential ingredients needed for growth and development (4). The question of whether any relationship exists between a normal physical development and breast-feeding has been investigated for many years. Despite the abundance of studies, not many have concentrated on the effects of breast-feeding and bottle-feeding on craniofacial development.

Growth of the craniofacial naturally involves an increase in size as well as dramatic changes in proportion. At birth, the cranium is slightly more than $60 \%$ complete, whereas the face is only $40 \%$ complete. The mandible is underdeveloped at this time, exhibiting an obtuse shape of the facial profile (12).

Growth does not mean just an increase in size but also changes in shape and orientation. During growth, the bone undergoes a remodeling and displacement process. The rate of change is different in different areas. The control of the growth involves a complex interaction with local functions responding to local signals, which must act in concert with other regions (13).

Growth is strongly influenced by genetic, functional and environmental factors. 
A sufficient intake of nutritious food is essential for normal growth. Under nutrition tends to accentuate the normal differential growth of the body tissues (14\&15).

Breast-feeding, bottle-feeding and use of dummies may have an influence on functional and environmental aspects of craniofacial and dental development.

The aim of this paper is to review whether there is an effect of the bottle-feeding and breast-feeding on the craniofacial and dentoalveolar growth. It is also to review whether there is an advantage of breast-feeding on craniofacial growth over bottlefeeding. In order to obtain the required information, we must address the following aspects:

1. The methods used to investigate the process of growth and feeding

2. Comparison between breast-feeding and bottle-feeding on the baby

3. Effects of the various feeding types on the craniofacial growth and the malocclusion

\section{THE METHODS USED TO INVESTIGATE THE PROCESS OF GROWTH AND FEEDING}

Growth can be analyzed by using x-ray film, 3-D imaging and physical measurements (16 \&17). On the other hand, the process of feeding can be evaluated using Cineradiographic (18), Ultrasound scanning (19) and Real-time Ultrasonographic (20).

\section{COMPARISON BETWEEN BREAST FEEDING AND BOTTLE FEEDING ON THE BABY}

\section{a) Process of breast feeding}

Infant feeding takes place by the rhythmic pumping action known as 'suckling'. In the first few days after birth, the lips are not readily poised, but a primitive rooting reflex exists and when the child is nursed, it turns its head naturally to the breast (21). In breast-feeding, the baby pulls and sucks the nipple into the mouth. Part of the areola is also held in the mouth and so the nipple is held as far back as the junction of hard and soft tissue palates (22). The lips form a seal and the mouth cavity is enlarged as the jaw moves. The whole of the lower jaw is raised and lowered alternately with a rocking motion. The tongue is protruded and remains in contact with the lower lip throughout. As the jaw is lowered, the body of the tongue moves downwards and forward. In X-ray films, this has been described as looking like a boat rocking upon waves. (23). The nipple is considerably extended and taken well back into the mouth, and the squeezing action is completed by the contraction of the floor of the mouth (21). The movement of the tongue is described as a peristaltic, rolling motion (24). This produces a low or negative pressure in the oral cavity, which facilitates the passage of milk from the nipple, although the oxytocin-induced milk let-down reflex triggered by touch receptors in and around the nipple is sufficient to give a flow of milk (25). The upward movement of the mandible with upward and backward movement of the body of the tongue increase pressure in the oral cavity and force the contents into the upper part of the pharynx, initiating relaxation and then contraction of the pharyngeal constrictors. Mandibular position is held by the masseter muscle and the medial pterygoid muscles; the tongue movements are a combination of intrinsic muscle contraction to change the shape of the tongue with the geniohyoid and genioglossus muscles controlling its general position. The airway is maintained during suckling $(23,25 \& 26)$.

Description of the action used for feeding from the breast is provided by Woodridge (22), Ardran et al. (18), Weber et al. (19) which used ultra sound scanning technique to image events in the baby's mouth. Further information on infant suckling has come from Novak et al. (20) using Real time sonographic technique.

Summary of the key features of the process used to suck from the breast $(18,19,20, \& 22)$ :

1. The infant gapes widely.

2. A large mouthful of breast tissue is then taken to form a teat.

3. This 'breast nipple' teat occupies as much space in the oral cavity as there is free tissue to fill it.

4. The shape of the 'breast nipple' teat is dictated by the internal geometry of the mouth.

5. The teat is elongated towards the back of the mouth by a combination of negative pressure and tongue and jaw action.

6. Milk is expressed from the breast by compression of the nipple against the palate by rhythmical pulsations of the surface of the tongue.

7. Negative suction pressure and the milk ejection also play significant roles.

8. The tongue is extended anteriorly.

9. The baby rests with the nipple teat moderately indented by the tongue.

b) Process of 10. bottle feeding

Bottle-feeding differs from suckling in breastfeeding. It does not have let down reflex and the child has to exert positive pressure on the teat with the tongue against the upper tooth pad (25). Teat and dummies vary in terms of size, shape, and the 
material that they are made from, compressibility, elasticity and flow rates. All these factors influence the action used to suck from the teat or dummy and its behavior during sucking process. The milk flow depends on the diameter of the teat's hole. (4 \& 27). The action used to bottle-feed has been well documented by Novak et al. (20) and Weber et al. (19) in their Real time Ultra sonographic studies of bottle-feeding.

Summary of the key features of the process used to suck from the bottle teat (19 \& 20):

1. The infants takes the teat in its mouth.

2. The teat is already formed and has a specific shape and is made from material, which is stiffer than breast tissue. It was found that teats were much less elastic than breast nipple teats (20).

3. The baby's mouth conforms to the shape of the teat.

4. Some elongation of teats occurs, but it is less than the elongation of the breast nipple teat.

5. A piston like stripping action is used to obtain milk from the bottle. It is more explosive and more powerful than the action used for breast-feeding. Greater pressure is applied to the teat than is applied to the breast nipple teat.

6. The baby rests with the teat expanded.

\section{C) Differences between breast-feeding and bottle-feeding processes}

There are several differences between breast feeding and bottle-feeding in terms of the processes, advantages and disadvantages. The differences have been simplified in Table 1.

\section{Differences between 'sucking' and 'suckling'}

Does the infant suckle or suck at the breast? The words 'sucking' and 'suckling' are used interchangeably in much of the literature, although some individuals strongly prefer one term to the other (34 \& 35). Similarities as well as differences are simplified in Table 2 and Figure 1.

\section{EFFECTS OF THE VARIOUS FEEDING TYPES ON THE CRANIOFACIAL GROWTH AND THE MALOCCLUSION}

Based on the information stated above, breastfeeding and bottle-feeding may alter the orofacial environment and have an effect on oral musculature function. Thus, it may have an effect on craniofacial and dental development. The significance of early signs of malocclusion is largely unresearched.
According to Moyers (36), studies addressing this question have been limited by being retrospective.

Straub (37) noted the marked differences between the mechanics of the infants sucking at bottle and breast, hypothesized that bottle feeding predisposes to both abnormal swallowing and finger sucking, which in turn can produce malocclusion.

Several theoretical mechanisms by which bottlefeeding might contribute to the development of malocclusion has been laid out. Among others are (a) a direct tropic effect of altered sucking mechanics on the growing facial bones of the infants, (b) an increased tendency toward abnormal swallowing pattern, and (c) an increased prevalence of nonnutritive either finger or pacifier (38 \& 39).

As early as 1914, Hellman (40) suggested an association between bottle-feeding and malocclusion, although the data upon which this conclusion was based do not include a sufficient number of controls to achieve statistical significance.

Later in 1968, Moss and Picton (41) reported their study of 553 children aged 2 to 12 years; the children were from Greece where the population was relatively poor and isolated, with a high rate of intermarriage. Breastfeeding was being replaced with bottle-feeding. In the age range from 2 to 6 years, significantly more breastfed children were found to have malocclusions than those fed by bottle $(\mathrm{P}<0.02)$.

Among other studies that found positive correlation between bottle-feeding and the cranio facial growth or malocclusion are Pottenger and Krohn (42), Labbok \& Hendershot (43), Adamiak (44) and Davis \& Bell (45).

Pottenger and Krohn (42) in their retrospective Cohort study of 327 infants found that bottle fed infants had reduce malar growth compared with breastfed infants. Malar growth was found to increase with increasing duration of breast-feeding. Infants that have been breastfed for more than 3 months have the best malar growth.

Labbok \& Hendershot 43) in their retrospective cohort study of the population with the sample size of 9,698 (age 3-17 years) found positive association between bottle feeding and malocclusion with the attributable risk of 44 percent.

Adamiak (44) in their retrospective cohort study of 748 samples (age 4-6 years) also found positive association between bottle feeding and occlusal anomalies.

In 1991, Davis \& Bell (45) conducted a single blind longitudinal study to measure the strength of association between feeding experiences in the first year of life and subsequent occlusal outcomes $(n=108$; average age 5 years). Feeding methods from birth were documented during postnatal visits and monthly well baby visits. At each visit, it was noted whether the baby was exclusively breast-fed, breastfed and bottle-fed in combination or exclusively 
Table 1. Differences between breast-feeding and bottle-feeding processes

\begin{tabular}{|c|c|c|}
\hline Parameters & Breastfeeding & Bottle feeding \\
\hline $\begin{array}{l}\text { Frequency of suckling/ } \\
\mathrm{mm}(28)\end{array}$ & $\begin{array}{l}\text { More frequent suckling } / \mathrm{mm} \\
\text { Continuous suckling }=88 \\
\text { Intermittent suckling }=80\end{array}$ & $\begin{array}{l}\text { Less frequent suckling } / \mathrm{mm} \\
\text { Continuous suckling }=63 \\
\text { Intermittent suckling }=58\end{array}$ \\
\hline Sucking action (24) & $\begin{array}{l}\text { Quality of movement and force applied. Breast } \\
\text { feeding involves rhythmical pulsations of the } \\
\text { surface of the tongue }\end{array}$ & $\begin{array}{l}\text { The action for bottle-feeding is a much more } \\
\text { powerful and explosive piston-like action.Greater } \\
\text { pressure is applied to the teat during bottle feeding } \\
\text { than is applied to the breast nipple teat. }\end{array}$ \\
\hline $\begin{array}{l}\text { Coordination of sucking } \\
\text { and breathing (29) }\end{array}$ & $\begin{array}{l}\text { Infants breathe within sucking bursts, and } \\
\text { appeared to alter subtle characteristics of } \\
\text { individual sucks to permits breathing within } \\
\text { sucking bursts }\end{array}$ & $\begin{array}{l}\text { Infants alternated bursts of sucking with 'burst' of } \\
\text { breathing and did not breathe within sucking } \\
\text { bursts. }\end{array}$ \\
\hline Breathing patterns (28) & $\begin{array}{l}\text { Shortening of expiration. } \\
\text { Prolonging of inspiration }\end{array}$ & $\begin{array}{l}\text { Prolonged expiration. } \\
\text { Shortening of inspiration }\end{array}$ \\
\hline Bradycardia (30) & 0 out of 10 infants & 2 out of 10 infants \\
\hline $\begin{array}{l}\text { Extension to grasp teat } \\
\text { (30) }\end{array}$ & $\begin{array}{l}\text { Extended opening of mouth to grasp mother's } \\
\text { nipple. Breast nipple teat is formed by the baby } \\
\text { according to the size of its own mouth and the } \\
\text { characteristics of the breast tissue. }\end{array}$ & $\begin{array}{l}\text { Less extension to grasprubber teat. When baby } \\
\text { feeds from an artificial teat the baby's mouth must } \\
\text { conform to the teat. }\end{array}$ \\
\hline Lips (31) & $\begin{array}{l}\text { Infant's lip flanged outward, relaxed and resting } \\
\text { against the breast to make a seal. }\end{array}$ & $\begin{array}{l}\text { Lips closer together and pursed to maintain } \\
\text { contact with rubber teat. }\end{array}$ \\
\hline Tongue $(19,22 \& 32)$ & $\begin{array}{l}\text { Tongue grooved around nipple; remains under } \\
\text { nipple throughout feed; moves in peristaltic } \\
\text { action from front to back }\end{array}$ & $\begin{array}{l}\text { Tongue upward and thrust forward against end of } \\
\text { teat, "piston like" to control milk flow. }\end{array}$ \\
\hline Jaw action (30) & Extensive mandibular (jaw) action & Minimal mandibular action. \\
\hline Duration (18) & $\begin{array}{l}\text { Duration of feeding varies from short (few } \\
\text { minutes) to long ( } 30 \text { minutes or longer) }\end{array}$ & Duration of feeding is usually $5-10$ minutes \\
\hline $\begin{array}{l}\text { Temperature and } \\
\text { quantity (33) }\end{array}$ & $\begin{array}{l}\text { Breast milk is available at the right temperature } \\
\text { and in the right amount }\end{array}$ & Varies \\
\hline Sounds (27) & $\begin{array}{l}\text { Silent, except for soft swallow sounds, and (in } \\
\text { older infants), cooing or 'singing' sounds of } \\
\text { pleasure }\end{array}$ & $\begin{array}{l}\text { High-pitched squeak at end of intake of air prior } \\
\text { to new suck }\end{array}$ \\
\hline $\begin{array}{l}\text { Nutritive and non } \\
\text { nutritive suckling (22) }\end{array}$ & $\begin{array}{l}\text { Includes nutritive and non-nutritive suckling } \\
\text { throughout the feed but less distinct differences. }\end{array}$ & Involves nearly exclusively nutritive suckling. \\
\hline
\end{tabular}

Table 2. Suckling and sucking comparisons

\begin{tabular}{l|l|l}
\hline Characteristics & Suckling & Sucking \\
\hline Tongue configuration & Flat, thin, cupped or bowl-shaped. & Flat, thin, slightly cupped or bowl-shaped \\
\hline Movement direction & In-out movement horizontal & Up-down movement vertical \\
\hline Range & Extension or protrusion no further out than middle of the lip & From mandible to anterior hard palate \\
\hline Lip approximation & Loose & Firm \\
\hline Expected state & Normally in early infancy & Normal later infancy, childhood, and adult \\
\hline
\end{tabular}

bottle-fed. The age at which solid food foods were introduced was also recorded. The clinical examination was performed. Among the orthodontic variable included in the survey were molar relationship, canine relationship, crowding, rotation, displacement, crossbites, overjet, overbite and 


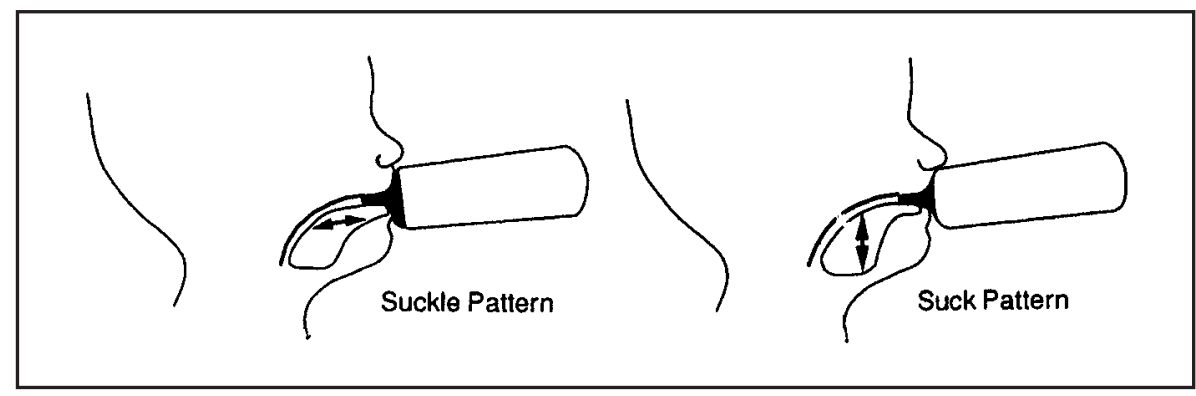

Figure 1: Sketch adapted from Arvedson \& Brodsky showing suckling and sucking comparison of tongue and mandibular action. Suckling is characterized by in-out movements and some jaw opening and closing; suckling by up-down tongue movements and less vertical jaw action.

congenital malformations.

They found a positive association between bottle feeding and overjet. Breast-feeding also lowers the risk of the anteroposterior malrelationships.

In contrast, there are at least three studies that found no association between the type of feeding and malocclusion. Those studies are by Humpreys and Leighton (46), Bishara et al. (47) and Legovic and ostrich (48).

In 1950, Humpreys and Leighton (46) reported no significant difference in frequency of bottle feeding among children with anteroposterior malocclusion as compared to controls in a survey of 2711 children in Britain aged 2 to $5 \frac{1}{2}$ years.

In 1987, Bishara et al. (47) conducted a longitudinal study involved 122 infants between 6 weeks and 18 months of age. They found no association between bottle feeding and malocclusion at 1.5 years. Comparisons of the absolute and percentage changes in the maxillary and mandibular arch parameters indicated no significant differences were present between the different groups at the end of the 18-month period. However the breast-fed infants showed the least amount of relative change in maxillary arch length and palatal depth. The authors suggested that further follow up was required to obtain conclusive results.

Four years later, Legovic \& Ostric (48) carried out their retrospective cohort study and found no association between bottle-feeding and malocclusion at 3 years. It must be noted that the breastfed group in the study contained both infants who were partially breastfed and exclusively breastfed infants. This misclassification could have acted to bias the study toward detecting no association between bottle-feeding and malocclusion.

Although studies show that there are no significant differences in the number of malocclusion between breast-fed and non breast-fed children, it has been found that breast-feeding encourages correct intermaxillary relationship (49).

In addition, there was one study that showed a trend of association between bottle-feeding and the need for orthodontic treatment but of marginal significance (38).
Overall, the best quality of study in methodological terms is that of Labbok and Hendershot (43). In this population based retrospective cohort study with over 9,000 subjects, children aged between 3 and 17 years who were bottle fed were 1.84 times more likely to have malocclusion than children who were breast fed. It was estimated that $44 \%$ of malocclusion in the population was due to bottle-feeding.

The findings of the studies on the association between type of feeding and craniofacial growth have been simplified in Tables 3 and 4 .

\section{Indirect effects of breast and bottle-feeding that may influence craniofacial and dental development}

Several questions need to be asked in order to find any indirect effect of bottle and breast-feeding on craniofacial and dental development such as:

(a) Does the type of feeding lead to any indirect abnormal process such as introduction to pacifier or dummy use, or lead to abnormal breathing and swallowing pattern that may affect the growth?

(b) Is there any relationship between bottle-feeding and dummy/thumb sucking habit?

It was found from various studies that use of dummies and sucking habits have an effect on the dental development. Five studies found a positive association between the use of dummies and malocclusion (50, 51, 52, $53 \& 54)$. Only a study by Bishara (47) found no association. However, infants were only 1.5 years of age at assessment and further follow up was required. Therefore it can be a confounding factor if the bottle or breast fed baby also have sucking habits and use the dummy.

There are a number of conflicting opinions regarding the effects of the feeding on the subsequent digital habit and dummy use that the child practices. Yarrow (55), Graber (56) and Najera (57) are of the opinion that bottle-feeding has significant influence on the child's acquiring digital habits. They generally observed that breast fed infants have the lowest prevalence of digital habits. 
Table 3. Epidemiological studies investigating the relationship between breastfeeding and bottle feeding and malocclusion (Positive association)

\begin{tabular}{|c|c|c|}
\hline $\begin{array}{l}\text { Investigators, year, sample } \\
\text { size, age at assessment }\end{array}$ & Type of study & Results or findings \\
\hline $\begin{array}{l}\text { Pottenger \& Krohn, } 1950 \\
\mathrm{~N}=327\end{array}$ & Retrospective cohort & Bottle-fed had reduced malar growth compared to breastfed infants. \\
\hline $\begin{array}{l}\text { Moss \& Picton, } 1968 \\
N=553 \\
2-6 \text { years }\end{array}$ & Cohort & $\begin{array}{l}\text { Significantly more breastfed children were found to have } \\
\text { malocclusion than those bottle fed }(P<0.02)\end{array}$ \\
\hline $\begin{array}{l}\text { Adamiak, } 1981 \\
=748 \\
\text { Age } 4-6 \text { years }\end{array}$ & $\begin{array}{l}\text { Population based } \\
\text { Retrospective cohort }\end{array}$ & +ve association between bottle feeding and occlusal anomalies. \\
\hline $\begin{array}{l}\text { Labbok \& Hendershot, } 1987 \\
\mathrm{~N}=9,698 \\
\text { Age 3-17 years }\end{array}$ & $\begin{array}{l}\text { Population based } \\
\text { Retrospective cohort }\end{array}$ & $\begin{array}{l}+ \text { ve association between bottle feeding and malocclusion. } R R=1.84 \\
\text { Attributable risk } \%=44 \%\end{array}$ \\
\hline $\begin{array}{l}\text { Davies \& Bell, } 1991 \\
\mathrm{~N}=108 \\
\text { Age } 5 \text { years }\end{array}$ & Retrospective cohort & $\begin{array}{l}+ \text { ve association between bottle feeding and overjet. } \mathrm{RR}=6.62(\mathrm{Cl} 1.5- \\
\text { 28.5) }\end{array}$ \\
\hline
\end{tabular}

Table 4. Epidemiological studies investigating the relationship between breastfeeding and bottle feeding and malocclusion (No association)

\begin{tabular}{l|l|l}
\hline $\begin{array}{l}\text { Investigators, year, sample size, } \\
\text { age at assessment }\end{array}$ & Type of study & Results or findings \\
\hline $\begin{array}{l}\text { Humphrey \& Leighton, } 1950 \\
\mathrm{~N}=2711 \\
\text { Age } 2 \text { to } 51 / 2 \text { years }\end{array}$ & Survey & $\begin{array}{l}\text { No significant difference between frequency of bottle feeding and } \\
\text { malocclusion }\end{array}$ \\
\hline $\begin{array}{l}\text { Bishara et al., } 1987 \\
\mathrm{~N}=122\end{array}$ & Cohort & No association \\
Age 1.5 years & & \\
\hline $\begin{array}{l}\text { Legovic \& Ostric, } 1991 \\
\mathrm{~N}=214 \\
\text { Age } 3 \text { years }\end{array}$ & Retrospective cohort & No association \\
\hline
\end{tabular}

On the other hands, Klackberg (58 \& 59), Traisman \& Traisman (60) and Porter (61) concluded that the method of feeding had no appreciable influence on the acquisition of digital habits.

Hornell et al. (62) analyzed the influence of thumb sucking and dummy used on breastfeeding pattern in exclusively breastfed infants, on the duration of exclusive breast-feeding, and on the total breastfeeding duration. They found that more frequent use of a pacifier was associated with shorter breastfeeding duration, even among a group of mothers who were highly motivated to breastfeed.

\section{DISCUSSION}

The evidence available is rather inconclusive. More numbers of papers are for the contention that the bottle-feeding has an effect on the craniofacial and dental development. Much of the study contain methodological flaws, hence reducing their likelihood of detecting effects if such effects truly exist.

\section{Problems with available evidence}

Nature of the study

The studies involve multifactorial causes and effects. Growth can be controlled by so many factors. It is rather difficult to point on a single cause that produces the effect. Furthermore, malocclusion and normal occlusion are not always definite and clear cut entities, particularly in the early stages of dentofacial development. Another contributory factors are the limited number of longitudinal studies describing the changes in the dental arches in infants fed with different modes.

\section{Measurement error}

There is no measurement of intensity or duration of breast-feeding. Partially breast fed 
infants are classified together with exclusively breastfed infants. This makes the breast-fed and bottle fed groups similar and has the effects of biasing studies towards detecting no differences between the groups in terms of rates of malocclusion.

Selection of control groups

In the majority of studies there is no control group of exclusively breastfed infants who have not used dummies. Sometimes the inclusion and exclusion criteria are not clearly described.

\section{Confounders}

There is no consideration of confounding factors such as use of dummies (in the case of studies on effects of bottle feeding and breast feeding), bottle feeding (in the case of studies on dummies) and age of introduction of solids.

\section{Information bias}

Some studies associate the type of feeding and the 'need of orthodontic treatment'. 'Need for orthodontic treatment' is a broader classification than malocclusion; for example, traumatic loose of deciduous tooth and the subsequent need for a space maintaining appliance might appear in this study as 'need for treatment' even if the child had a perfect occlusion. Therefore 'the need of orthodontic treatment' might not represent the 'malocclusion' in its association with the type of feeding.

\section{Extrapolation of the results.}

Generalization frequently made inappropriately. For example in the absence of demonstrated dose relationship between bottle feeding and malocclusion, one leads to normal mandibular growth and occlusal relations even where infants are partially bottle fed. Some studies extrapolate the result of association as the causation and vice versa. The term 'association' is used to describe the relationship between two variables and the term 'casuality' is normally used to describe the relationship of causes and the effects they produce (63).

Future research

Future research needs to be carried out with attention to details paid on the method section. Any review of the literature should require Meta analysis or systematic reviews. Searching of the literature should be carried out using both manual and computer search.

\section{SUMMARY}

In summary, the breast-feeding seems to have more positive impact on the cranio facial development and good dental development. There is no strong evidence that the jaws and dental arches of the bottle fed child will be smaller or less well related than those of the breast fed child. One of the major problem in extrapolating the results was most study suffered from methodological problems.

\section{ACKNOWLEDGEMENTS}

The authors would like to express their special thanks to Puan Sabariah Ishak, Puan Norjinah (President of Malaysian Breastfeeding Association), Dr Nurul Huda Mohd Thiyauddin and Dr. Haizal Hussaini for their assistance.

\section{REFERENCES}

1. Keith R.M, Wood C. Infant Feeding and Feeding Difficulties. Churchill Livingstone. 1977. Edinburgh. 53-61.

2. Blanc B, Biochemical aspects of human milkcomparison with bovine milk. World Rev. Nutr. Diet 1981; 36: 1-89.

3. Roberton N.R.C. A Manual of Normal Neonatal Care. 2nd edition. Arnold. 1997. London. 119-167.

4. Henschel D, Inch S. Breastfeeding A Guide For Midwives. . Books for Midwives Press. 1992. 1130.

5. Department of Health and social Security. Present day practice in infant feeding: third report. Report on health and social subjects, 37, HMSO, London.

6. Sinusas K, Gagliardi A. Initial management of breastfeeding. Kansas City 2001; 64: 981-989.

7. Wood B.S, Walker-Smith J.A. MacKeith's Infant feeding and Feeding Difficulties. Churchill Livingstone. 1981. 6th ed. Edinburgh. 53-65.

8. Collins C.T, Ryan P, Crowther A.A, McPhee A.J, Paterson S, Hiller J.E. Effects of bottles, cups, and dummies on breast feeding in preterm infants: a randomized controlled trial. BMJ. 2004; 329: 193-198.

9. Kliethermes P.A, Cross M.L, Lanese M.G, Johnson K.M, Simon S.D. Transitioning preterm infants with nasogastric tube supplementation: increased likelihood of breastfeeding. J Obstet Gynecol Neonatal Nurs. 1999; 28: 264-273. 
10. Rocha N.M, Martinez F.E, Jorge S.M. Cup or bottle for preterm infants: effects on oxygen saturation, weight gain, and breastfeeding. J Hum Lact. 2002; 18: 132-138.

11. Kramer M.S. Does breast-feeding protect against atopic disease? : Biology, methodology and a golden jubilee of controversy. J Paed. 1988; 112: 181-190.

12. Ranly DM, Craniofacial Growth. The Dental Clinics of North America. 2002; 44: 457-470.

13. Ranly DM, A Synopsis of Craniofacial Growth. 2nd ed. Prentice Hall International Editions.1988. 82-158.

14. Krogman W.M. Child growth, Ann Arbor, Mich, 1972, The University of Michigan Press.

15. Eveleth P B, Tanner J M; World Wide variation in human growth, 2nd ed, Cambridge, Mass, 1990, Cambridge University Press.

16. Buckler J.M.H. Growth Disorders in Children. BMJ Publishing Group.1994. 14-55.

17. Hajeer M.Y, Millet D.T, Ayoub A.F, Siebert J.P. Application of 3D imaging in orthodontics. Part 1. J Orthod. 2004; 31: 62-70.

18. Ardran GM, Kemp FH, Lind J. A cineradiographic study of breastfeeding. Bri J Radiology 1958; 31: 156-162.

19. Weber F, Woolridge MW, Baum JD. An ultrasonographic analysis of sucking and swallowing in newborn infants. Dev Med and Child Neurology 1986; 28: 19-24.

20. Novak AJ, Smith WL Erenberg A. An imaging evaluation of artificial nipples during bottlefeeding. Arch Paed and Adolescent Med 1994; 148: 40-42.

21. Houston WJB, Stephens CD, Tulley WJ. A Textbook of Orthodontics. 2nd edition. Wright. Oxford. 1992.

22. Woolridge MW. The 'anatomy' of infant sucking. Midwifery 1986; 2: 164-171.

23. Ferguson D.B. Physiology for dental Students. Wright. 1988. London 257-264.

24. Weber F, Woolridge M.W, Baum J.D. An ultrasonographic analysis of sucking and swallowing in newborn infants. Dev Med and Child Neurology. 1986; 28: 19-24.
25. Ferguson DB. Oral Bioscience. Churchill Livingstone. 1999. Edinburgh. 247-278.

26. Bosma J.F. Form and function in the mouth and pharyx of the human infants. In Control Mechanism in Craniofcial Growth. The center for Human Growth and Development. The University of Michigan. 1975. Michigan. 9-23.

27. Riordan J, Ayerbach K. Breastfeeding and human Lactation. Jones and Bartlett Publishers. Boston. 1993.

28. Matthew O.P regulation of breathing patterns during feeding. In Matthew O.P, Ambrogio G.S. Eds: respiratory function of the upper airway, 1988. New York. Marcel Dekker. 535-560.

29. Meier P.P. Suck-breathe pattern during bottle and breastfeeding for preterm infants. In Major Controversies in infant nutrition. Eds. David T.J. The Royal Society of Medicine. 1996. London

30. Maher S.M. An overview of solutions to breastfeeding and sucking problems. Franklin Park III, La Leche League International. 1988. 4.

31. McBride M.C, Danner S.C. Sucking disorders in neurologically impaired infants. Assessment and facilitation of breastfeeding. Clin Perinatol. 1987; 14: 109-130.

32. Marmet C, Shell E. Training neonates to suck correctly. MCN. 1984; 9: 401-407.

33. Fox, B.A., Cameron A.G. Food Science, Nutrition and Health. 6th ed. Arnold. 1995 London.

34. Arvedson J.C, Brodsky L. Pediatric Swallowing and Feeding. Whurr Publisher. 1993. London.

35. Montagu A. In Raphael D. Eds. Breastfeeding and Food Policy in a Hungry World. Academic Press. 1979. New York. 189-193.

36. Moyers R.E. Handbook of orthodontics. $4^{\text {th }}$ ed. Yearbook Medical Publishers. 1988. Chicago.

37. Straub W.J. Malfunction of the tongue. Am J Orthod. 1960; 46: 404-424.

38. Meyers A, Hertzberg J, Bottle feeding and Malocclusion: Is there an association? Am J Orthod Dentofac Orthop, 1988; 93: 149-152. 
39. Backlund E. Facial growth and the significance of oral habits, mouth breathing, and soft tissues for malocclusion. Acta Odontol Scand. 1963; 21 (suppl 36): 55-73.

40. Hellman M. A study of some etiological factors of malocclusion. Dent. Cosmos 1914; 54: 10171031 .

41. Moss J.P, Picton D.C. The problems of dental development among children on a Greek Island. Dent. Prac 1968; 18: 442-448.

42. Pottenger FM, Krohn B. Influence of breastfeeding on facial development. Arch Paeds 1950; 57: 454-461.

43. Labbok MH, Hendershot GE. Does breastfeeding protect against malocclusion? An analysis of the 1981 child health supplement to the national health interview survey. Am J Prev Med 1987; 394: 227-232.

44. Adamiak M. Breast feeding and bottle-feeding: The etiology of malocclusion. Br Dent J 1981; 151: 296-302.

45. Davis DW \& Bell PA. Infant feeding practices and occlusal outcomes: A longitudinal study. J Canadian Dent Assoc. 1991; 57: 593-594.

46. Humphreys H.F, Leighton B.C. A survey of antero-posterior abnormalities of the jaws in children between the ages of two and five and a half years of age. Br. Dent J. 1950; 88: 3-15.

47. Bishara SE, Nowak AJ, Kohout FJ, Heckert DA, Hogan MM. Influence of non-nutritive sucking methods on the development of dental arches: longitudinal study on the first 18 months of life. Paeds Dent 1987; 9: 13-21.

48. Legovic M, Ostric L, The effects of feeding methods on the growth of the jaws in infants. J Dent Child: 1991; May-June: 253-255.

49. Malagola C, Mandraffino A.G, De Paolis M, Ruolo dell'allattamento nella genesi delle malocclusioni. Mondo orthodontico, 11: 39-44 September-October, 1986 as cited from Legovic M, Ostric L, The effects of feeding methods on the growth of the jaws in infants. J Dent Child: 1991; May-June: 253-255.

50. Bowden BD. The effecs of digital and dummy sucking on arch widths, overbite and overjet. A longitudinal study. Aust Dent J. 1966; December: 396-404.
51. Larsson E. Dummy and finger sucking habits with special attention to their significance for facial growth and occlusion. The effect of early dummy and finger sucking habits in 16 year old children compared with children without earlier sucking habit. Swed Dent J 1978; 1: 23-33.

52. Melsen B, Stensgaard K, Pedersen J. Sucking habits and their influence on swallowing pattern and prevalence of malocclusion. Eur J Orthod : 1979; 1: 271-280.

53. Paunio P, Rautava P Sillanpaa M. The Finnish Family Competence Study. The effects of living conditions on sucking habits in 3-year-old Finnish children and the association between these habits and dental occlusion. Acta Odontol Scand 1993; 51: 23-29.

54. Svedmyr B. Dummy sucking: a study of its prevalence, duration, and malocclusion consequences. Swed Dent J. 1979; 3: 205-210.

55. Yarrow L.J. The relationship between nutritive sucking experiences in infancy and non-nutritive sucking in children. J Genet Psychol 1954; 84 : 149-62.

56. Graber T.M. The "three M's": musles, malformation, a malocclusion. Am J Orthod. 1963; 49: 418-450.

57. Najera A. A critical evaluation of early feeding procedures and their implication of oral-facial morpho-physiology and related factors. M.S. thesis, St Louis Univ., 1963.

58. Klackenberg G. Thumbsucking: frequency and etiology. Paediatrics 1949; 4: 418-423.

59. Klackenberg G.A prospective longitudinal study of children. Acta Paed Scand. 1971; Supplement 224: 1-239.

60. Traisman A.S, Traisman H.S. Thumb sucking and finger sucking: a study of 2650 infants and children. J Pediatr 1958; 52: 566-572.

61. Porter D.R. Applications and interrelations of oral habits. J Dent Child 1964; 31: 164-170.

62. Hornell AC, Kylberg E, Hofvander Y, GebreMedhin M. Breastfeeding patterns in relation to thumb sucking and pacifier use. Pediatrics. 1999; 104: 50-53.

63. Everitt B.S. The Cambridge Dictionary of Statistics in the Medical Sciences. Cambridge University Press. 1995. Cambridge. 